Article

\title{
Removal of Calcium Carbonate Water-Based Filter Cake Using a Green Biodegradable Acid
}

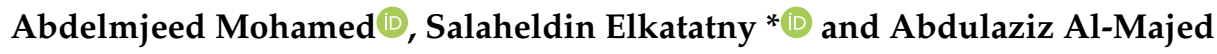 \\ College of Petroleum Engineering and Geosciences, King Fahd University of Petroleum \& Minerals, \\ 31261 Dhahran, Saudi Arabia; abdelmjeed.mohamed@kfupm.edu.sa (A.M.); aamajed@kfupm.edu.sa (A.A.-M.) \\ * Correspondence: elkatatny@kfupm.edu.sa; Tel.: +96-65-9466-3692
}

Received: 18 December 2019; Accepted: 24 January 2020; Published: 30 January 2020

check for updates

\begin{abstract}
The filter cake is a very thin layer of solid particles deposited from the drilling fluid onto the surface of the drilled formation. This is essential during the drilling process as it reduces fluid filtrate invasion, contributing for the well's integrity. When the drilling processes are over, this formation must be removed efficiently to allow for the primary cement jobs to be conducted efficiently, and for hydrocarbons to be produced without any restrictions. The removal process of the filter cake is challenging and requires specific techniques, depending on several factors including the filter cake homogeneity, drilling fluid components, weight of materials used, and the continuous phase of the drilling fluid (i.e., water or oil). This study evaluates the use of green biodegradable removal acid (GBRA) to dissolve calcium carbonate water-based filter cake. The removal efficiency of this new acid was analyzed using filtration and removal tests, conducted on a ceramic filter disc and real core samples at $212{ }^{\circ} \mathrm{F}$. Then, the new formulation was subjected to physical properties measurements and biodegradation and corrosion tests. Furthermore, the performance of the new acid formulation was compared with $10 \mathrm{wt} . \%$ hydrochloric acid $(\mathrm{HCl})$ to ensure its efficiency. The obtained results showed that the new acid formulation was effective at removing the filter cake, with a removal efficiency greater than $90 \%$. The retained permeability was $100 \%$ and $94 \%$ with the ceramic filter disc and the real limestone core sample, respectively, confirming the good removal performance of the new acid formulation. The corrosion rate of GBRA ( $50 \mathrm{wt} . \%$ ) at $212^{\circ} \mathrm{F}$ was $0.032 \mathrm{lb} / \mathrm{ft}^{2}$, which was within the acceptable range according to oil industry practices (i.e., less than $0.05 \mathrm{lb} / \mathrm{ft}^{2}$ if the temperature is less than $\left.250^{\circ} \mathrm{F}\right)$, while $\mathrm{HCl}(10 \mathrm{wt} . \%)$ yielded a high corrosion rate of $0.68 \mathrm{lb} / \mathrm{ft}^{2}$.
\end{abstract}

Keywords: biodegradable acid; filter cake removal; calcium carbonate; water-based; drilling fluid

\section{Introduction}

In drilling operations, the drilling fluid is introduced to achieve many objectives, such as lubricating and cooling the drill bit and the drill string [1], transferring the drilled cuttings to the surface while drilling, and suspending the drilled cuttings when the drilling operation is stopped [2]. Another main function of drilling fluid is to control the well by applying hydrostatic pressure to prevent formation fluids from invading the wellbore. Moreover, the drilling fluid is used to ensure wellbore stability by forming a thin and low permeability film on the wall of the well under an overbalance condition called filter cake [3-6].

For the drilling mud to prevent blowout and suppress the formation pressure, the drilling mud formulation usually contains a weighting agent such as barite, hematite, manganese tetroxide, or calcium carbonate [7-14]. These chemicals are added to the drilling fluid to attain the desired density [15]. Consequently, these high-weight additives are the main source of formation damage-related problems, particularly in the producing zones, and have a considerable effect on the formed filter cake structure. 
The filter cake is a thin impermeable layer with permeability ranging from 0.01 to $0.0001 \mathrm{mD}$ [16], which is formed on the face of the permeable formation [17], as shown in Figure 1. Filter cake formation is required to stabilize the drilled formations, minimize the drilling fluid filtrate into the drilled formation [15,18,19], and reduce solid particle invasion into the oil-bearing formations [20]. However, after the drilling operations, the drilling fluids and the filter cake film must be removed from the wellbore to enable a successful primary cementing job. Also, filter cake removal is mandatory before the start of production operations to avoid impeding the flow capacity at the wellbore [21].

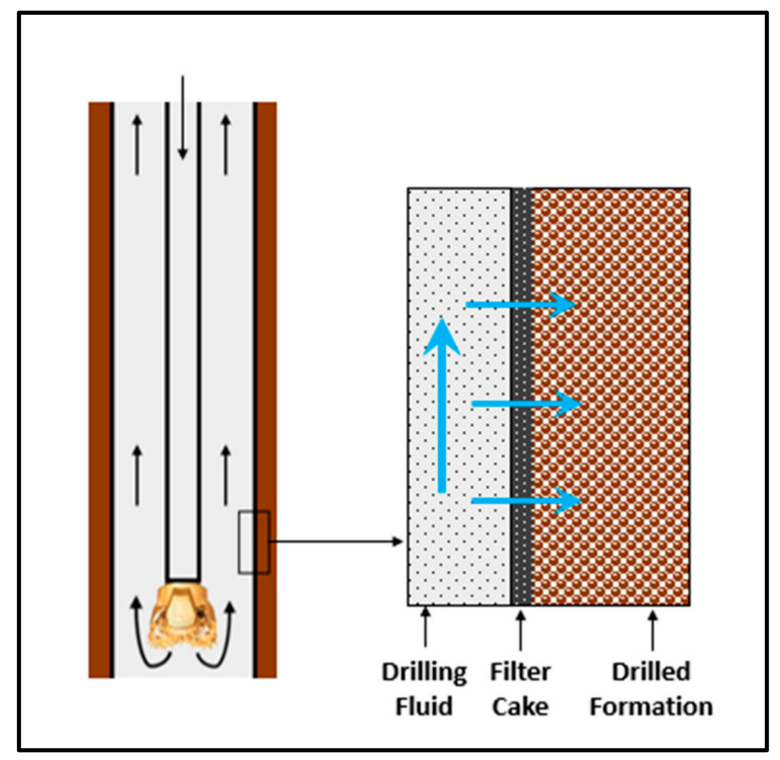

Figure 1. The filter cake formation on the surface of the drilled formation.

The preflush fluids are designed to be injected after the drilling operation and before injecting the cement slurry to thoroughly wipe the remaining mud in the annular space [22]. These fluids are designed to be efficient in cleaning the drilling mud and chemically compatible with drilling mud and cement slurry. Additionally, they should be able to prevent sludge or emulsion formation and modify the formation rock wettability in some cases [23].

Filter cake removal is a complicated task, as the filter cake layer has different structural characteristics for different drilling fluid types (i.e., water- or oil-based drilling fluid) and different weighting additives [15]. The weighting material constitutes 70 to $80 \mathrm{wt} \%$ of the filter cake layer $[19,24,25]$. Therefore, the removal efficiency of the filter cake mainly depends on the solubility of the weighting material of the treatment chemical. Another factor that determines the required number of stages to dissolve the filter cake is the compatibility of the removal fluid with the polymer breaker.

Rostami and Nasr-El-Din [26] developed a new self-destructing calcium carbonate-weighted water-based drilling fluid. The new formulation is based on the addition of polylactic acid (PLA), which is an ester that liberates lactic acid and alcohol when dissolved in water. The PLA is mainly used to dissolve the calcium carbonate from the filter cake body after hydrolysis with water. The cleaning solution was able to remove 75 to $78 \mathrm{wt}$ \% of the filter cake formed by the new self-destructing drilling mud, which was higher than the normal drilling fluid.

Mahapatra and Kosztin [27] examined the possibility of using magnesium peroxide $\left(\mathrm{MgO}_{2}\right)$ as an internal breaker for the calcium carbonate-based filter cake on laboratory and field scales. By soaking the filter cakes formed by different drilling fluids with different concentrations of $\mathrm{MgO}_{2}$ particles into $15 \mathrm{wt}$.\% hydrochloric acid $(\mathrm{HCl})$ solution for $2 \mathrm{~h}$, the $10 \mathrm{wt} \% \mathrm{MgO}_{2}$ particles were found to best enhance the filter cake removal efficiency. The optimized drilling mud formulation in an Omani field showed good results in two out of the three wells, where the actual oil production rate from the two wells exceeded the expected rate. 
Elkatatny and Nasr-El-Din [28] proposed a low $\mathrm{pH}$ formulation based on tetrasodium glutamate diacetate (GLDA) to dissolve the calcium carbonate filter cake in a two-stage process. The two-stage process was recommended because of the incompatibility between the GLDA and the polymer breaker. During the first stage, $10 \mathrm{wt} . \%$ of the amylase enzyme was used to break the polymer, while GLDA with a $\mathrm{pH}$ of 3.3 was used as a treatment solution in the second stage. Ba geri et al. [19] studied the impact of sandstone cuttings on the removal efficiency of calcium carbonate-filter cake during drilling horizontal laterals in sandstone reservoirs. It was concluded that the dissolution rate of the calcium carbonate in GLDA, at a $\mathrm{pH}$ of 3.8, decreased from 100 to $80 \mathrm{wt} . \%$ when the filter cake layer contained 20 wt.\% sandstone cuttings.

Elkatatny and Mahmoud [29] investigated the enzyme compatibility with $20 \mathrm{wt} . \%$ chelating agent solutions at different $\mathrm{pH}$ values for the removal of calcium carbonate filter cake. Three different chelating agents, i.e., ethylene diamine tetra-acetic acid (EDTA), diethylenetriamine penta-acetic acid (DTPA), and tetrasodium glutamate diacetate (GLDA), with different $\mathrm{pH}$ values were used. It was found that using chelating agent solutions alone was not able to remove the starch after soaking for $12 \mathrm{~h}$. This indicated that the use of an enzyme to break down the polymer is necessary. The high-throughput assays enzyme (HTA) broke the starch completely after $6 \mathrm{~h}$ of reaction. The compatibility study confirmed that all the chelating agents considered in this work were not compatible with the HTA enzyme, indicating that the treatment should be conducted in two stages. The two-stage process was able to remove the filter cake with $100 \mathrm{wt}$ \% removal efficiency.

Mohamed et al. [30] and Elkatatny [31] introduced a new acid formulation to dissolve a calcium carbonate oil-based filter cake. Their formulation contained 50 vol.\% biodegradable acid to dissolve the filter cake, 5 vol.\% mutual solvent to remove the oil film surrounding the filter cake to allow acid-filter cake reaction, and 45 vol.\% water. Their formulation was effective in removing the filter cake, with $100 \mathrm{wt} . \%$ removal efficiency, and retained permeability. A further stimulation was observed on limestone core samples after the removal process because of the acid-rock interaction.

Although many new fluid formulations have been introduced to remove calcium carbonate-based filter cake in water-based fluids, the need for a cheap, compatible, environmentally-friendly, and efficient removal fluid still prevails. In this study, a new fluid formulation was introduced to dissolve calcium carbonate filter cake in water-based drilling fluids. The new formulation comprises $50 \mathrm{wt} . \%$ biodegradable acid; the remaining $50 \mathrm{wt} . \%$ is water. The new acid formulation was able to efficiently remove the filter cake, minimizing the treatment cost by reducing the number of stages and the duration of the acid treatment. This formulation also mitigated the impact of removal fluid on the environment. First, the materials used in this work are described and the experimental procedures are explained; then, our findings are discussed and summarized.

\section{Material}

A water-based drilling fluid was prepared using the fluid formulation described in Table 1. The drilling fluid consisted of xanthan polymer as a viscosifier, starch as a fluid loss control additive, potassium chloride as a clay stabilizer, potassium hydroxide to increase the $\mathrm{pH}$ of the drilling fluid, sodium sulfite as an oxygen scavenger, and calcium carbonate (with an average particle size, $\mathrm{D}_{50}=50 \mu \mathrm{m}$ ) as a weighting material and bridging agent. The drilling fluid additives were added in order and mixed for a specific time. Twenty-five-micron ceramic filter discs and Indiana limestone core samples (with an average permeability of $k=25 \mathrm{mD}$, diameter of $d=2.5^{\prime \prime}$, and thickness $h=1.7^{\prime \prime}$ ) were used as a filtration medium. 
Table 1. Drilling fluid formulation on a lab-scale.

\begin{tabular}{cc}
\hline Additive & Amount \\
\hline Water & $308 \mathrm{~g}$ \\
Defoamer & $0.33 \mathrm{~cm}^{3}$ \\
Xanthan gum & $1.5 \mathrm{~g}$ \\
Starch & $6 \mathrm{~g}$ \\
Potassium chloride & $80 \mathrm{~g}$ \\
Potassium hydroxide & $0.3 \mathrm{~g}$ \\
Sodium sulfite & $0.25 \mathrm{~g}$ \\
Calcium carbonate $(50 \mu \mathrm{m})$ & $30 \mathrm{~g}$ \\
\hline
\end{tabular}

A green biodegradable acid (GBRA) was used as a removal fluid. The GBRA was an acid solution formulated with a combination of a catalyst and a reagent added to $\mathrm{HCl}$, creating a biodegradable, nonbioaccumulating alternative to inhibited and potentially hazardous $\mathrm{HCl}$. During its synthesis, water was added to $\mathrm{HCl}$ to quench the exothermic reaction created, thereby significantly increasing the strength of the acid. Simultaneously, a cathodic stimulation was created to reduce the corrosiveness by a factor of 50 at ambient temperatures [30,31]. Steel coupons were used in the corrosion test to measure the corrosion rate at different acid concentrations.

\section{Experimental Work}

\subsection{GBRA Properties and Biodegradation Test}

The acid formulation was analyzed by measuring its physical properties to optimize the treatment operation. These properties were viscosity, density, and surface tension. The density was measured using a graduated cylinder. A total of $100 \mathrm{~cm}^{3}$ of the fluid was poured into the graduated cylinder. The weight of the cylinder was recorded before and after pouring the fluid using a sensitive weight balance. Then, the difference in the weight was divided by the volume of the fluid to obtain its density. The viscosity and surface tension were measured using a kinematic viscosity tester and a tensiometer, respectively. All the measurements were performed at ambient temperature and under atmospheric pressure.

The acid formulation was sent to an accredited laboratory to measure the acid biodegradability using the OECD 301B biodegradation test. This is an aerobic biodegradation test where a material is introduced to an inoculum in a closed environment and the biodegradability of the acid is measured by carbon dioxide $\left(\mathrm{CO}_{2}\right)$ evolution 28 days later [32-34].

\subsection{HPHT Filtration Tests}

Filtration experiments were carried out to evaluate the filter cake removal efficiency with the new acid formulation. The experiments were performed in two stages: firstly, the filtration part formed the filter cake and secondly, the removal part evaluated the removal efficiency after soaking the filtration medium in the acid formulation for $6 \mathrm{~h}$. Both steps were conducted at $212^{\circ} \mathrm{F}$, and $300 \mathrm{psi}$. Twenty-five-micron ceramic filter discs and real Indiana limestone core samples were used as a filtration medium. Two hundred milliliters of the removal fluid that was used consisted of $50 \mathrm{wt} . \%$ biodegradable acid; the remaining $50 \mathrm{wt} . \%$ was water. The weight and thickness of the filtration medium were measured before and after each step to characterize the filter cake and to calculate the removal efficiency. Moreover, the initial and final permeabilities of the filtration medium were measured to evaluate the retained permeability after the treatment. The removal efficiency and retained permeability were calculated using Equations (1) and (2):

$$
\text { Removal ef ficiency, wt. } \%=\frac{\text { Removed filter cake weight }}{\text { Initial filter cake weight }} \times 100
$$




$$
\text { Retained permeability, } \%=\frac{\text { Final permeability }}{\text { Initial permeability }} \times 100 \ldots
$$

\subsection{Corrosion Test}

The corrosion test was performed to evaluate the corrosion rate of the new acid formulation, to ensure its applicability in the oil industry. The test was conducted at $212^{\circ} \mathrm{F}$ under $300 p s i$ using an aging cell. One hundred milliliters of the removal fluid was poured into the aging cell, and a steel coupon was immersed in the fluid. Then, the cell was closed, pressurized, and heated. The test was run for $6 \mathrm{~h}$, as per oil industry practices. Afterwards, the coupon was removed, washed, dried, and weighed, and the corrosion rate was calculated with Equation (3), using the weight difference and the surface area of the coupon. As per oil industry standards, an acceptable corrosion rate is $\leq 0.05 \mathrm{lb} / \mathrm{ft}^{2}$. The corrosion rate of GBRA was measured for two concentrations, i.e., 25 and $50 \mathrm{wt} . \%$, and then compared with $10 \mathrm{wt} . \% \mathrm{HCl}$.

$$
\text { Corrosion rate, } \frac{l b}{f t^{2}}=\frac{W_{\text {before }}-W_{a f t e r}}{\text { Surface Area }}
$$

\section{Results and Discussions}

\subsection{GBRA Properties and Biodegradability}

The properties of the new acid formulation were measured to optimize the treatment job in the field. GBRA had a viscosity of $\mu=1.58 \mathrm{cP}$, density of $\rho=1.1 \mathrm{~g} / \mathrm{cm}^{3}$, surface tension of $\sigma=31.4 \mathrm{mN} / \mathrm{m}$, and a $\mathrm{pH}$ of 0.02 . These properties were measured at room temperature and under atmospheric pressure. GBRA biodegradability was measured using the OECD 301B biodegradation test by the theoretical evaluation of carbon dioxide $\left(\mathrm{ThCO}_{2}\right)$. The GBRA achieved a biodegradation rate of $65 \%$ by day 28 , exceeding the requirements for ready biodegradability ( $60 \%$ by day 28 ) based on OECD test criteria [33]. Consequently, a plateau of $81 \%$ was achieved by day 40 (Figure 2). With growing environmental concerns, this biodegradation rate would make GBRA a good candidate to remove calcium carbonate-filter cake from oil and gas wells.

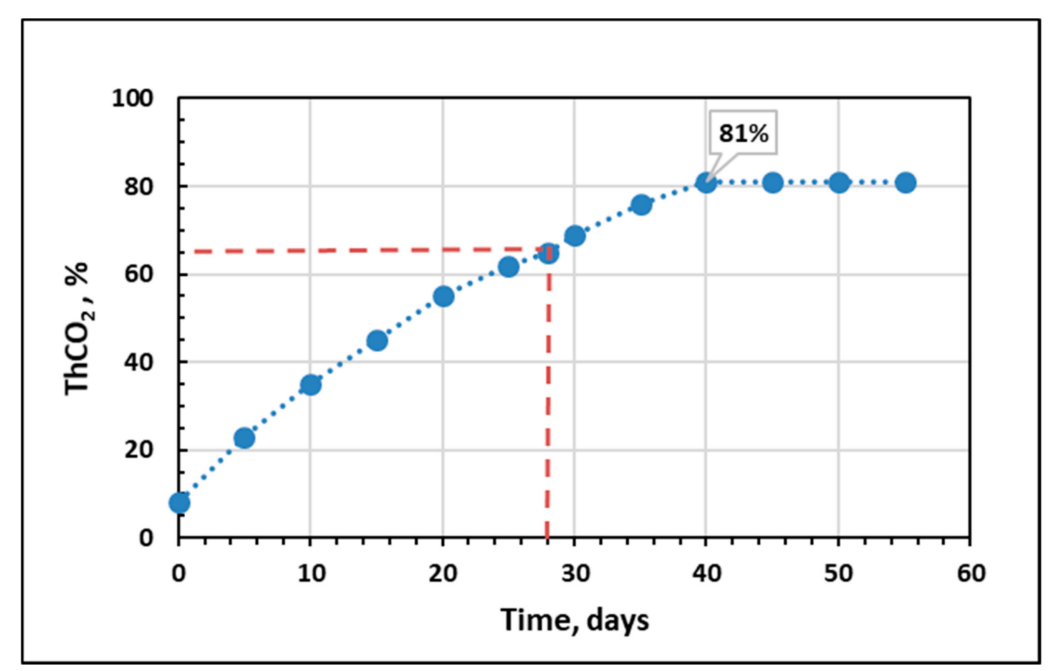

Figure 2. Acid biodegradation by $\mathrm{CO}_{2}$ evolution using OECD $301 \mathrm{~B}$ test.

\subsection{Filter Cake Removal and Retained Permeability}

Filtration experiments were carried out to form the filter cake on the filtration medium and to perform the removal process. Figure 3 shows the filtration performance of the drilling fluid using a 25-micron ceramic filter disc and Indiana limestone core sample at $212^{\circ} \mathrm{F}$ under 300 psi. With a 
ceramic disc, the drilling fluid yielded a total filtrate volume of $9.9 \mathrm{~cm}^{3}$ after the standard test time, i.e., $30 \mathrm{~min}$. The filter cake weight and thickness were $5.57 \mathrm{~g}$ and $1.3 \mathrm{~mm}$, respectively. The filtration performance on the core sample was similar to that on the ceramic disc, with a slightly higher fluid filtrate, i.e., $10.5 \mathrm{~cm}^{3}$. The removal process was performed on ceramic filter discs and real core samples under the same conditions. The filtration medium was soaked in $200 \mathrm{~cm}^{3}$ of $50 \mathrm{wt} . \%$ GBRA for $20 \mathrm{~h}$. Figures 4 and 5 show the ceramic disc and core sample before and after the filtration and removal tests. From the clean surface of the filtration mediums, GBRA was effective in removing the filter cake, as its calculated removal efficiency was greater than $95 \mathrm{wt} . \%$ in both cases.

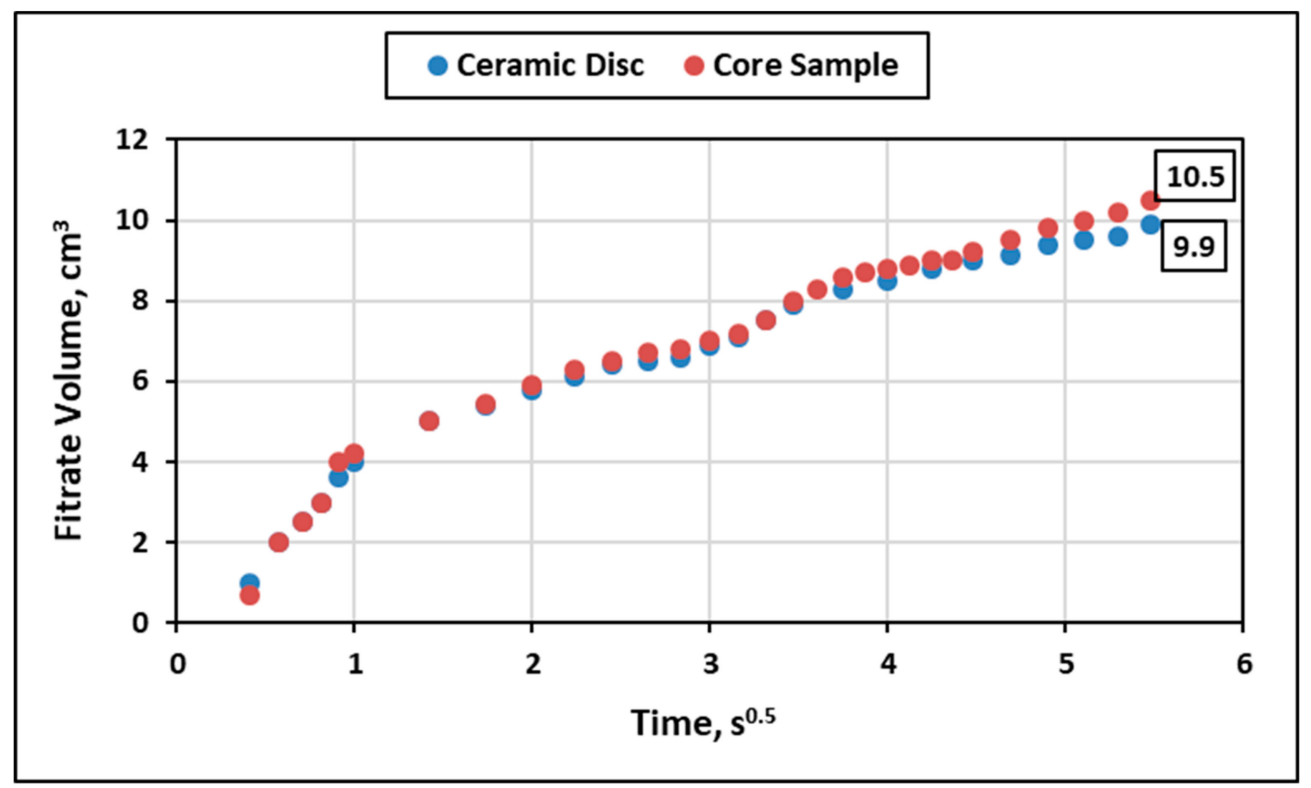

Figure 3. Filtration performance of the water-based drilling fluid using different filtration mediums.

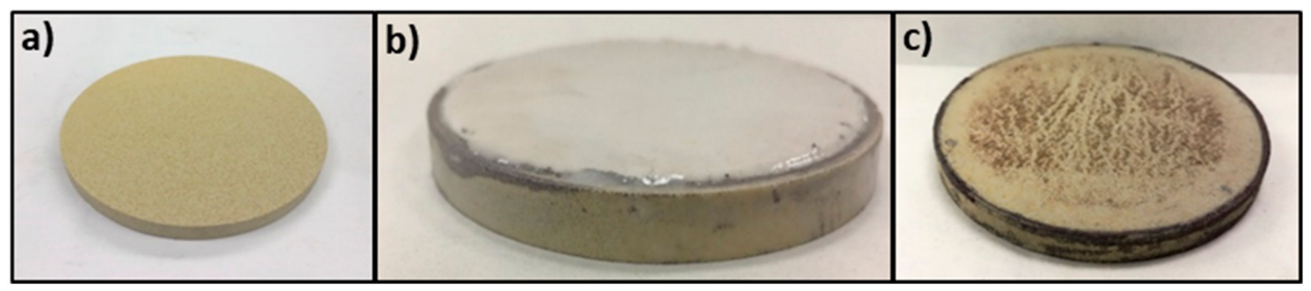

Figure 4. Ceramic filter disc: (a) before filtration, (b) after filtration, and (c) after removal with 50 wt.\% green biodegradable removal acid (GBRA).

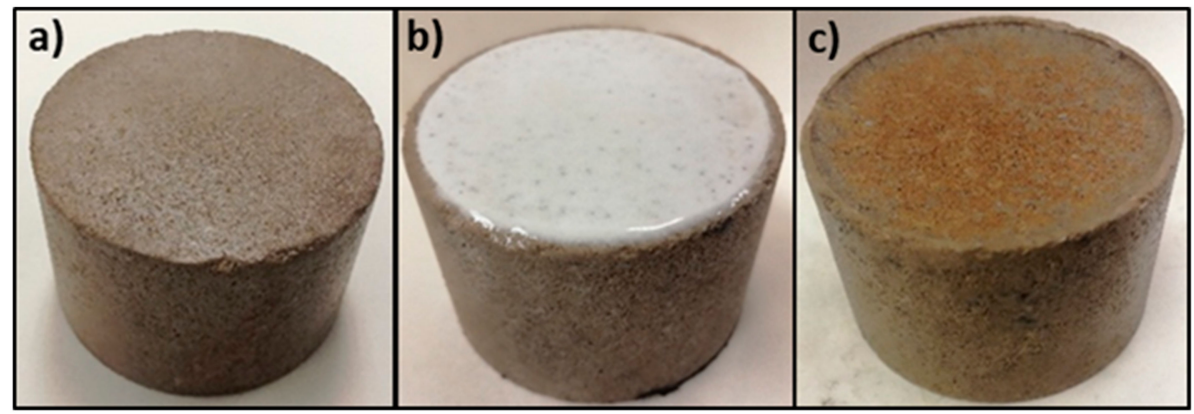

Figure 5. Indiana limestone core sample: (a) before filtration, (b) after filtration, and (c) after removal with 50 wt. $\%$ GBRA.

Furthermore, the initial and final permeability of the core sample were measured to evaluate the removal of the internal damage caused by filtrate and solids invasion. For this purpose, real Indiana 
limestone cores, with a 1.7" length and 2.5" diameter, were used to perform the filtration and removal tests. The initial core permeability was $25 \mathrm{mD}$ measured using distilled water. After $20 \mathrm{~h}$ soaking in $50 \mathrm{wt} . \%$ GBRA, $94 \%$ of the initial permeability was restored, and the final permeability was $23.5 \mathrm{mD}$. This confirmed that the new acid system could be used to remove the internal damage caused by the fine particles invasion during the filtration process.

\subsection{Corrosion Test}

The corrosion test was conducted for the new acid formulation at two different concentrations of GBRA, i.e., $25 \mathrm{wt} . \%$ and $50 \mathrm{wt.} \%$, at $212^{\circ} \mathrm{F}$. As shown in Figure 6, GBRA yielded a very low corrosion rate with both concentrations. The corrosion rate at $25 \mathrm{wt} . \%$ was $0.025 \mathrm{lb} / \mathrm{ft}^{2}$ while, when the acid concentration increased to $50 \mathrm{wt} . \%$, it was $0.032 \mathrm{lb} / \mathrm{ft}^{2}$. Both corrosion rates were within the acceptable range, i.e., $<0.05 \mathrm{lb} / \mathrm{ft}^{2}$, as per the oil industry practices. Figure 7 shows that no noticeable damage was observed on the surface of the coupon after the corrosion test with $50 \mathrm{wt} . \%$ GBRA. GBRA was titrated using the titration test to determine the acid concentration in the solution. It was found that GBRA contained $20 \mathrm{wt} . \%$ of converted $\mathrm{HCl}$, thus $50 \mathrm{wt} . \%$ GBRA consists of only $10 \mathrm{wt}$. \% HCl. Therefore, the corrosion rate of the new formulation was compared with $10 \mathrm{wt} . \% \mathrm{HCl}$ at the same conditions. Ten percent $\mathrm{HCl}$ was found to be very corrosive; the corrosion rate was $0.68 \mathrm{lb} / \mathrm{ft}^{2}$, which is much higher than that of $50 \mathrm{wt.} \%$ GBRA (Figure 6).

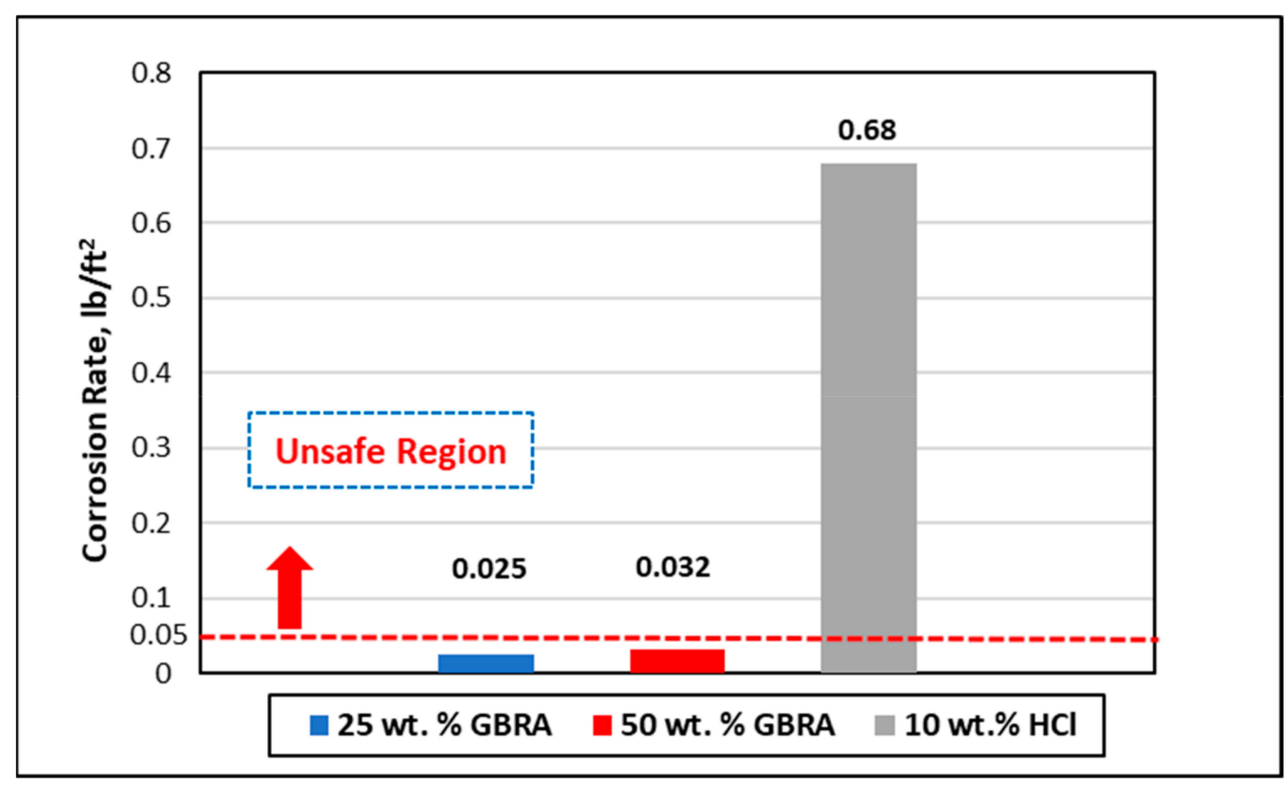

Figure 6. The corrosion rate of GBRA and hydrochloric acid $(\mathrm{HCl})$.

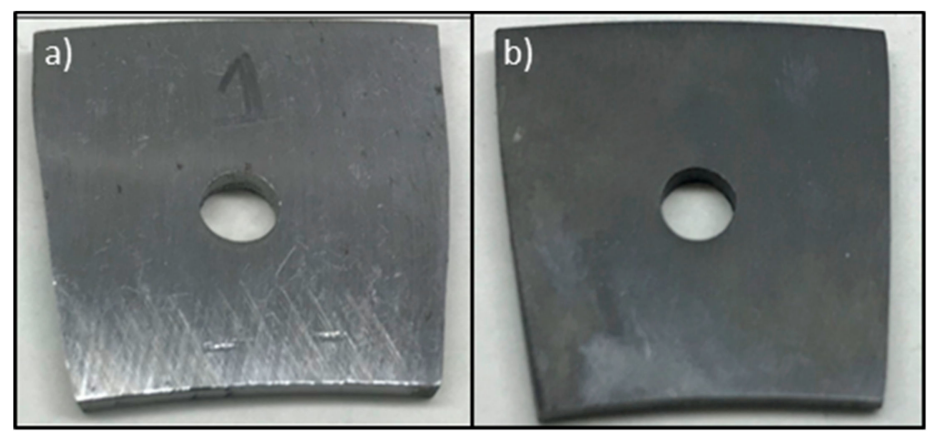

Figure 7. Steel coupon: (a) before and (b) after the corrosion test using $50 \mathrm{wt} . \%$ GBRA at $212{ }^{\circ} \mathrm{F}$. 


\section{Summary and Conclusions}

In summary, a new acid formulation was introduced to remove calcium carbonate water-based filter cake. Based on the obtained results, the following conclusions can be drawn:

1. The new acid formulation was efficient in removing the calcium carbonate water-based filter cake after $20 \mathrm{~h}$ soaking time with a removal efficiency and retained permeability of greater than $90 \%$.

2. GBRA (50 wt.\%) yielded a corrosion rate of $0.032 \mathrm{lb} / \mathrm{ft}^{2}$ at $212^{\circ} \mathrm{F}$ without adding any corrosion inhibitor that is below the standard corrosion rate approved by the oil and gas industry $\left(<0.05 \mathrm{lb} / \mathrm{ft}^{2}\right.$ at a temperature less than $\left.250^{\circ} \mathrm{F}\right)$, while the corrosion rate of $\mathrm{HCl}(10 \mathrm{wt} . \%)$ was $0.68 \mathrm{lb} / \mathrm{ft}^{2}$.

3. GBRA ( $50 \mathrm{wt} . \%$ ) has a viscosity of $\mu=1.58 \mathrm{cP}$, density of $\rho=1.1 \mathrm{~g} / \mathrm{cm}^{3}, \mathrm{pH}$ of 0.02 , and surface tension of $\sigma=31.4 \mathrm{mN} / \mathrm{m}$. These properties were measured at room temperature.

4. The new acid formulation achieved a biodegradation rate of $65 \%$ by day 28 using $\mathrm{ThCO}_{2}$ measurement, exceeding the requirements for ready biodegradability; a plateau of $81 \%$ was achieved by day 40 .

5. The high removal efficiency, ready biodegradability, and low corrosion rate make this new acid formulation a good candidate for calcium carbonate-filter cake removal in oil and gas wells.

Author Contributions: Conceptualization, S.E.; Methodology, A.M. and S.E.; Formal Analysis, A.M., S.E., and A.A.-M.; Investigation, A.M. and S.E.; Resources, S.E. and A.A.-M.; Data Curation, A.M. and S.E.; Writing-Original Draft Preparation, A.M.; Writing-Review \& Editing, A.M., S.E. and A.A.-M.; Visualization, A.M.; Supervision, S.E. and A.A.-M.; Project Administration, S.E. All authors have read and agreed to the published version of the manuscript.

Funding: This research received no external funding.

Acknowledgments: The authors wish to acknowledge King Fahd University of Petroleum and Minerals (KFUPM) for utilizing the various facilities in carrying out this research. Many thanks are due to the anonymous referees for their detailed and helpful comments. Special acknowledge to Enviroklean Product Development, Inc. (EPDI) and Maeen Companied Companies for providing the acid system.

Conflicts of Interest: The author declares no conflict of interest.

\section{References}

1. Gordon, C.; Lewis, S.; Tonmukayakul, P. Rheological properties of cement spacer: mixture effects. In Proceedings of the AADE Fluids Conference and Exhibition, Houston, TX, USA, 8-9 April 2008; AADE-08-DF-HO-09.

2. Fink, J.K. Petroleum engineer's guide to oil field chemicals and fluids; Gulf Professional Publishing: Waltham, MA, USA, 2015; ISBN 9780128037348.

3. Bourgoyne, A.T., Jr.; Millheim, K.K.; Chenevert., M.E.; Young, F.S., Jr. Applied Drilling Engineering; Society of Petroleum Engineers: Houston, TX, USA, 1986; ISBN 978-1-55563-001-0.

4. Caenn, R.; Darley, H.C.H.; Gray, G.R. Composition and Properties of Drilling and Completion Fluids. Gulf Professional Publishing: Houston, TX, USA, 2011; ISBN 9780123838582.

5. Hossain, M.E.; Al-Majed, A.A. Fundamentals of Sustainable Drilling Engineering. John Wiley \& Sons, Inc.: Hoboken, NJ, USA, 2015.

6. Rabia, H. Well Engineering and Construction; Entrac Petroleum: London, UK, 2001; Chapter 6; p. 203, ISBN 978-1-55563-207-6.

7. Al-Yami, A.S.; Nasr-El-Din, H.A. An Innovative Manganese Tetroxide/KCl Water-Based Drill-in Fluid for HT/HP Wells. In Proceedings of the SPE Annual Technical Conference and Exhibition, Anaheim, CA, USA, 11-14 November 2007; Society of Petroleum Engineers (SPE): Houston, TX, USA, 2007.

8. Basfar, S.; Mohamed, A.; Elkatatny, S.; Al-Majed, A. A Combined Barite-Ilmenite Weighting Material to Prevent Barite Sag in Water-Based Drilling Fluid. Matererials 2019, 12, 1945. [CrossRef] [PubMed]

9. Elkatatny, S.M. Evaluation of Ilmenite as Weighting Material in Water-Based Drilling Fluids for HPHT Applications. In Proceedings of the Kuwait International Petroleum Conference and Exhibition, Kuwait City, Kuwait, 14-16 December 2009. 
10. Mohamed, A.; Basfar, S.; Elkatatny, S.; Al-Majed, A. Prevention of Barite Sag in Oil-Based Drilling Fluids Using a Mixture of Barite and Ilmenite as Weighting Material. Sustainability 2019, 11, 5617. [CrossRef]

11. Sloan, J.; Brooks, J.; Dear, S. A New, Nondamaging, Acid-Soluble Weighting Material. J. Pet. Technol. 1975, 27, 15-20. [CrossRef]

12. Tehrani, A.; Cliffe, A.; Hodder, M.H.; Young, S.; Lee, J.; Stark, J.; Seale, S. Alternative Drilling Fluid Weighting Agents: A Comprehensive Study on Ilmenite and Hematite. In Proceedings of the IADC/SPE Drilling Conference and Exhibition, Fort Worth, TX, USA, 4-6 March 2014; Society of Petroleum Engineers (SPE): Houston, TX, USA, 2014.

13. Tuntland, O.B.; Herfjord, H.J.; Lehne, K.A.; Haaland, E. Iron oxide as Weight Materials for Drilling Muds. Erdoel-Erdgas Zeitschrif 1982, 97, 300-302.

14. Walker, C. Alternative Weighting Material. J. Pet. Technol. 1983, 35, 2158-2164. [CrossRef]

15. Rugang, Y.; Guancheng, J.; Wei, L.; Tianqing, D.; Hongxia, Z. Effect of water-based drilling fluid components on filter cake structure. Powder Technol. 2014, 262, 51-61. Available online: https://doi.org/10.1016/j.powtec. 2014.04.060 (accessed on 5 November 2019).

16. Hanssen, J.E.; Jiang, P.; Pedersen, H.H.; Jørgensen, J.F. New Enzyme Process for Downhole Cleanup of Reservoir Drilling Fluid Filtercake. SPE International Symposium on Oilfield Chemistry: Houston, TX, USA, 1999.

17. Civan, F. A Multi-Phase Mud Filtrate Invasion and Wellbore Filter Cake Formation Model. In Proceedings of the International Petroleum Conference and Exhibition of Mexico, Veracruz, Mexico, 10-13 October 1994; Society of Petroleum Engineers (SPE): Houston, TX, USA, 1994.

18. Bageri, B.S.; Mahmoud, M.A.; Al-Mutairi, S.H.; Kuwait, C.; Abdulraheem, A. Filter Cake Porosity and Permeability Profile Along the Horizontal Well and Their Impact on Filter Cake Removal. In Proceedings of the International Petroleum Technology Conference, Doha, Qatar, 6-9 December 2015; Society of Petroleum Engineers (SPE): Houston, TX, USA, 2015.

19. Ba geri, B.S.; Mahmoud, M.A.; Al-Mutairi, S.H.; Abdulraheem, A. Effect of Sand Content on the Filter Cake Properties and Removal During Drilling Maximum Reservoir Contact Wells in Sandstone Reservoir. J. Energy Resour. Technol 2016, 138, 32901. Available online: https://doi.org/10.1115/1.4032121 (accessed on 1 December 2019). [CrossRef]

20. Bageri, B.S.; Al-Mutairi, S.H.; Mahmoud, M.A. Different Techniques for Characterizing the Filter Cake. In Proceedings of the SPE Unconventional Gas Conference and Exhibition, Muscat, Oman, 28-30 January 2013; Society of Petroleum Engineers (SPE): Houston, TX, USA, 2013.

21. Fink, J. Petroleum Engineer's Guide to Oil Field Chemicals and Fluids, 2nd ed.; Elsevier: Amsterdam, The Netherlands, 2015; Chapter 9; pp. 299-316. Available online: https://doi.org/10.1016/B978-0-12803734-8.00009-6 (accessed on 25 November 2019).

22. Mcdonald, M.; Li, X.; Lim, B. A formulated silicate-based pre-flush \& spacer for improved wellbore cleaning and wetting. In Proceedings of the AADE Fluids Technical Conference and Exhibition, Houston, TX, USA, 15-16 April 2014; AADE-14-FTCE-55.

23. Quintero, L.; Christian, C.; Halliday, W.; White, C.; Dean, D.; Courtney, G. New spacer technology for cleaning and water wetting of casing and riser. In Proceedings of the AADE Fluids Conference and Exhibition, Houston, TX, USA, 8-9 April 2008. AADE-08-DF-HO-01.

24. Bageri, B.S.; Al-Majed, A.A.; Al-Mutairi, S.H.; Ul-Hamid, A.; Sultan, A.S. Evaluation of Filter Cake Mineralogy in Extended Reach and Maximum Reservoir Contact Wells in Sandstone Reservoirs. In Proceedings of the SPE/IADC Drilling Conference, Amsterdam, The Netherlands, 5-7 March 2013; Society of Petroleum Engineers (SPE): Houston, TX, USA, 2013.

25. Geri, B.S.B.; Mahmoud, M.; Al-Majed, A.A.; Al-Mutairi, S.H.; AbdulAzeez, A.; Shawabkeh, R. Water Base Barite Filter Cake Removal Using Non-Corrosive Agents. In Proceedings of the Middle East Oil Show, Manama, Kingdom of Bahrain, 6-9 March 2017; Society of Petroleum Engineers (SPE): Houston, TX, USA, 2017.

26. Rostami, A.; Nasr-El-Din, H.A. New Technology for Filter Cake Removal. In Proceedings of the SPE Russian Oil and Gas Conference and Exhibition, Moscow, Russia, 26-28 October 2010; Society of Petroleum Engineers (SPE): Houston, TX, USA, 2010. 
27. Mahapatra, S.K.; Kosztin, B. Magnesium Peroxide Breaker for Filter Cake Removal. In Proceedings of the SPE Europec/EAGE Annual Conference and Exhibition, Vienna, Austria, 23-26 May 2011; Society of Petroleum Engineers (SPE): Houston, TX, USA, 2011.

28. Elkatatny, S.M.; El Din, H.A.N. Removal of water-based filter cake and stimulation of the formation in one-step using an environmentally friendly chelating agent. Int. J. Oil Gas Coal Technol. 2014, 7, 169. [CrossRef]

29. Elkatatny, S.M.; Mahmoud, M. Investigating the Compatibility of Enzyme with Chelating Agents for Calcium Carbonate-Filter Cake Removal. Arab. J. Sci.Eng. 2018, 43, 2309-2318. Available online: https: //doi.org/10.1007/s13369-017-2727-4 (accessed on 20 November 2019). [CrossRef]

30. Mohamed, A.; Elkatatny, S.; Basfar, S. One-Stage Calcium Carbonate Oil-Based Filter Cake Removal Using a New Biodegradable Acid System. In Proceedings of the SPE Kuwait Oil and Gas Show and Conference, Mishref, Kuwait, 13-16 October 2019; Society of Petroleum Engineers (SPE): Houston, TX, USA, 2019.

31. Elkatatny, S. One-Stage Calcium Carbonate Oil-Based Filter Cake Removal Using a New Biodegradable Acid System. Sustainability 2019, 11, 5715. [CrossRef]

32. Itävaara, M.; Vikman, M. An overview of methods for biodegradability testing of biopolymers and packaging materials. J. Polym. Environ. 1996, 4, 29-36. [CrossRef]

33. Biodegradability, Ready. OECD guideline for testing of chemicals. OECD 1992, 71, 1-9.

34. Sweetlove, C.; Chenèble, J.-C.; Barthel, Y.; Boualam, M.; L'Haridon, J.; Thouand, G. Evaluating the ready biodegradability of two poorly water-soluble substances: comparative approach of bioavailability improvement methods (BIMs). Environ. Sci. Pollut. Res. 2016, 23, 17592-17602. [CrossRef] [PubMed]

(C) 2020 by the authors. Licensee MDPI, Basel, Switzerland. This article is an open access article distributed under the terms and conditions of the Creative Commons Attribution (CC BY) license (http://creativecommons.org/licenses/by/4.0/). 